\title{
Long-term fertilization and intensive cropping enhance carbon and nitrogen accumulated in soil clay-sized particles of red soil in South China
}

\author{
$\mathrm{Hu} \mathrm{Xu}^{1,2} \cdot$ Kailou Liu ${ }^{3} \cdot$ Wenju Zhang $^{1} \cdot$ Yichao Rui $^{4} \cdot$ Jingye Zhang $^{1} \cdot$ Lei Wu$^{1} \cdot$ Gilles Colinet $^{2} \cdot$ Qinghai Huang $^{3} \cdot$ \\ Xianni Chen ${ }^{5} \cdot$ Minggang $\mathrm{Xu}^{1}$
}

Received: 14 May 2019 / Accepted: 6 December 2019/Published online: 18 December 2019

(C) Springer-Verlag GmbH Germany, part of Springer Nature 2019

\begin{abstract}
Purpose Understanding the underlying mechanism of soil carbon $(\mathrm{C})$ and nitrogen $(\mathrm{N})$ accumulation is of great significance for soil $\mathrm{C}$ sequestration and climate change mitigation, as well as soil fertility improvement. The objective of this study was to evaluate the response of $\mathrm{C}$ and $\mathrm{N}$ accumulation in aggregates and fine soil particles to long-term mineral fertilizer and manure application.

Materials and methods Five treatments from a long-term experiment with double maize cropping were examined in this study, i.e., (1) no fertilizer (control); (2) mineral nitrogen, phosphorus, and potassium application (NPK); (3) doubled application rate of the NPK (2NPK); (4) pig manure alone (M); and (5) mineral NPK fertilizers and manure combination (NPKM). By using physical particle-sized fractionation, we analyzed soil organic carbon $(\mathrm{OC})$ and total nitrogen $(\mathrm{N})$, and $\delta^{13} \mathrm{C}$ of $\mathrm{OC}$ in bulk soil and aggregates $(53-2000 \mu \mathrm{m})$ and, coarse silt-sized fraction $(5-53 \mu \mathrm{m})$, fine silt-sized fraction $(2-5 \mu \mathrm{m})$, and clay-sized fraction $(<2 \mu \mathrm{m})$ under those five treatments.

Results and discussion Fertilizer application for 24 years, particularly M and NPKM treatments, significantly increased the concentration and proportion of $\mathrm{OC}$ and total $\mathrm{N}$ associated with aggregates and clay-sized fraction as compared with control. Manure application significantly increased the proportion of OC by 6.6-7.8 points in aggregates, whereas it was by $22.6-25.0$ points in clay-sized fraction. Clay-sized fraction-associated $\mathrm{C}$ and $\mathrm{N}$ showed a non-linear response to $\mathrm{C}$ and $\mathrm{N}$ accumulation in bulk soil, contributing approximately $47 \%$ and $69 \%$ to soil OC and total N, respectively. Moreover, the mass proportion of aggregates and the mass ratio of aggregates to fine soil particles increased significantly with $\mathrm{C}$ accumulation in fine silt-sized and clay-sized fraction.

Conclusions Organic carbon and total nitrogen accumulation in soil clay-sized particles play important role in soil $\mathrm{C}$ and $\mathrm{N}$ sequestration in red soil. Our results also suggested that $\mathrm{C}$ accumulation in fine soil particles might benefit soil aggregation in intensive cropping system of South China.
\end{abstract}

Keywords Long-term fertilization · Organic carbon · Physical particle-sized fractionation · Soil aggregation $\cdot$ Total nitrogen

Responsible editor: Caixian Tang

Electronic supplementary material The online version of this article (https://doi.org/10.1007/s11368-019-02544-8) contains supplementary material, which is available to authorized users.

Wenju Zhang

zhangwenju01@caas.cn

Minggang Xu

xuminggang@ caas.cn

1 National Engineering Laboratory for Improving Quality of Arable Land, Institute of Agricultural Resources and Regional Planning, Chinese Academy of Agricultural Sciences, Beijing 100081, China
2 Gembloux Agro-Bio Tech, University of Liege, 5030 Gembloux, Belgium

3 Jiangxi Institute of Red Soil, Scientific Observational and Experimental Station of Arable Land Conservation in Jiangxi, Ministry of Agriculture, Nanchang 331717, China

4 Rodale Institute, Kutztown, Harrisburg, PA 19530, USA

5 College of Agriculture, Henan University of Science \& Technology, Luoyang 471003, China 


\section{Introduction}

Soil organic carbon (SOC) and nitrogen (N) in agroecosystem have attracted much attention over the past two decades due to their crucial roles in soil fertility, crop productivity, and climate change mitigation (Paustian et al. 2016; Ghimire et al. 2017). Higher SOC and N levels are usually associated with higher crop productivity contributed by the enhanced nutrient cycling, and physicochemical and biological properties (Bell et al. 2014). On the other hand, greater crop yield can also contribute to a greater amount of crop residues incorporated into soils, thereby enhancing $\mathrm{C}$ and $\mathrm{N}$ accumulation (Zhang et al. 2010). Therefore, appropriate agricultural management practices, such as crop rotation, optimal fertilization, and organic amendments, are highly recommended to enhance soil $\mathrm{C}$ sequestration by increasing crop residues return and $\mathrm{C}$ and $\mathrm{N}$ input (Fan et al. 2019; Wen et al. 2019).

SOC and $\mathrm{N}$ are mainly stabilized with soil minerals. Numerous studies have confirmed that most organic carbon (OC) and $\mathrm{N}$ are bound in silt-sized and clay-sized fraction, highlighting the predominant role of fine mineral particles in $\mathrm{C}$ and N stabilization (Antil et al. 2005; Poeplau et al. 2017). Some studies show that $\mathrm{C}$ and $\mathrm{N}$ within particle-sized fractions display contrasting decomposition characteristics (Chan et al. 2002; Koiter et al. 2017). Generally, organic matter in aggregates $(>53 \mu \mathrm{m})$ is active and sensitive to management practices changed. In contrast, fine soil particles $(<53 \mu \mathrm{m})$ have a larger specific surface area, and can adsorb and stabilize $\mathrm{C}$ and $\mathrm{N}$ through ligand exchange, hydrogen bonding, and hydrophobic effects (Schulten and Leinweber 1991; Leinweber and Reuter 1992). Accordingly, OC and $\mathrm{N}$ in fine soil particles usually have a long turnover time and contribute greatly to C and N stock (Balesdent et al. 2000; Denef et al. 2007). It is believed that long-term manure application can significantly enhance $\mathrm{C}$ and $\mathrm{N}$ accumulation in all particlesized fractions in arable soils (Liang et al. 2014; Zhang et al. 2015a). Some studies show that mineral fertilizer application has little influence on, or even decreases $\mathrm{C}$ and $\mathrm{N}$ concentration in different particle-sized fractions (Aoyama et al. 1999; Ling et al. 2014). Some other studies also suggest that longterm fertilization can increase $\mathrm{C}$ distribution in aggregates and silt-sized fraction, but not affected in clay-sized fraction of topsoil (Dong et al. 2017). Therefore, more evidence is needed to unravel the impact of mineral fertilizer and manure application on $\mathrm{C}$ and $\mathrm{N}$ stabilization in soil particles.

Red soil accounts for about $30 \%$ of the total area in China's arable land. This highly weathered soil is widely distributed in tropical and subtropical regions of southern China with abundant precipitation and thermal resource. However, over a long period of intensive cultivation and farming, soil fertility and productivity in these areas have seriously degraded due to the high risk of soil erosion and acidification resulted from intensive cropping and excess use of chemical nitrogen fertilizer (Guo et al. 2010). Moreover, developed from the Quaternary red clay, the red soil usually is poorly structured (Xu et al. 2015). Study from this area indicates that long-term organic manure increases $\mathrm{C}$ accumulation in the macroaggregates and micro-aggregates (Huang et al. 2010). Due to the intensive cropping in this area, we hypothesized that organic $\mathrm{C}$ derived from crops or applied manure would be bond to fine soil particles $(<53 \mu \mathrm{m})$ first, resulted in $\mathrm{C}$ enrichment in the fine particles, then acted as binding agents to benefit the formation of soil aggregates. To test this hypothesis, we select a 24-year field experiment in upland red soil to explore the response of $\mathrm{OC}$ and total $\mathrm{N}$ in soil fractions to long-term fertilizer application.

\section{Materials and methods}

\subsection{Experiment site description}

This long-term experiment site $\left(28^{\circ} 37^{\prime} \mathrm{N}, 116^{\circ} 26^{\prime} \mathrm{E}\right)$ was located in Jinxian County, Jiangxi province. The red soil was classified as ferralic cambisol (FAO 1988) in this study. This site had an annual average temperature of $17.7^{\circ} \mathrm{C}$ and average rainfall of $1727 \mathrm{~mm}$. The experiment started in 1986 . The initial topsoil $(0-20 \mathrm{~cm})$ physiochemical properties were as follows: $\mathrm{SOC}, 8.93 \mathrm{~g} \mathrm{~kg}^{-1}$; total $\mathrm{N}, 0.98 \mathrm{~g} \mathrm{~kg}^{-1}$; available $\mathrm{N}$, $60.30 \mathrm{mg} \mathrm{kg}^{-1}$; $\mathrm{pH}$ value, 6.00; bulk density, $1.19 \mathrm{~g} \mathrm{~cm}^{-3}$.

\subsection{Cropping practice}

Prior to the long-term experiment, the field was cultivated with peanuts $\left(\mathrm{C}_{3}\right.$ plant, Arachis hypogaea $)$ and/or soybean $\left(\mathrm{C}_{3}\right.$ plant, Glycine $\max L$.) for several years. Since 1986, double maize $\left(\mathrm{C}_{4}\right.$ plant, Zea mays $L$.) plantation had been conducted. Spring and summer maize were sown in mid-April and late July and harvested at early July and early November, respectively. Herbicides and pesticides were applied during the growth periods when necessary. Crops were harvested by cutting manually. The above-ground biomass was removed from the field after the harvest, leaving about 5-10-cm height of stalks in situ. Grains and straws yield for each crop were recorded yearly after air-dried.

\subsection{Experiment design}

The experiment was conducted based on a completely randomized design with three replicates. Five treatments were included in this study, i.e., (1) no fertilizer (control); (2) mineral nitrogen, phosphorus, and potassium application (NPK); (3) doubled application rate of the NPK (2NPK); (4) pig manure alone (M); and (5) mineral NPK fertilizers and pig manure combination (NPKM). Each plot was randomly designed 
with an area of $22.2 \mathrm{~m}^{2}$ and was isolated by $100 \mathrm{~cm}$ cement baffle plates.

Mineral N, P, and $\mathrm{K}$ fertilizers were applied in urea, calcium-magnesia phosphate, and potassium chloride, respectively (Table 1). For NPK and NPKM treatments, mineral N, $\mathrm{P}$, and $\mathrm{K}$ fertilizers were applied at rates of $60 \mathrm{~kg} \mathrm{~N} \mathrm{ha}^{-1}$ season $^{-1}, 15 \mathrm{~kg} \mathrm{P} \mathrm{ha}^{-1}$ season $^{-1}$ and $30 \mathrm{~kg} \mathrm{~K} \mathrm{ha}^{-1}$ season $^{-1}$, respectively. Manure was applied at $15 \mathrm{tha}^{-1}$ (fresh basis weight) under M and NPKM treatments for each maize season. All mineral $\mathrm{P}, \mathrm{K}$ fertilizers and organic manure were used as a base fertilizer. A total of $70 \%$ of mineral $\mathrm{N}$ fertilizer was applied as topdressing, and the rest $\mathrm{N}$ fertilizer was applied 2 weeks after seeding. The content of carbon, nitrogen, and water in pig manure were $376 \mathrm{~g} \mathrm{~kg}^{-1}, 33.14 \mathrm{~g} \mathrm{~kg}^{-1}$, and $716 \mathrm{~g} \mathrm{~kg}^{-1}$, respectively.

\subsection{Sampling and analysis}

Soil samples $(0-20 \mathrm{~cm})$ were collected after summer maize harvest in 2010. Each plot was randomly sampled for 5-10 cores in $5-\mathrm{cm}$ diameter. These soil cores from each plot were thoroughly mixed and air-dried, and then passed through $2.00 \mathrm{~mm}$ and $0.25 \mathrm{~mm}$ sieve for chemical analyses.

Air-dried soil samples $(<2000 \mu \mathrm{m})$ were fractionated into aggregates $(53-2000 \mu \mathrm{m})$, coarse silt-sized fraction (5$53 \mu \mathrm{m})$, fine silt-sized fraction $(2-5 \mu \mathrm{m})$, and clay-sized $(<$ $2 \mu \mathrm{m}$ ) fraction with a modified method (Wu et al. 2005). In this method, aggregates $(53-2000 \mu \mathrm{m})$ was selected by wet sieving, and mineral-associated fractions $(<53 \mu \mathrm{m})$ by centrifugation of the suspension after wet sieving according to Stokes' law (Amelung et al. 1998; Wu et al. 2005). Before wet sieving, the air-dried samples were pretreated as follows: air-dried soil was capillary rewetted to field capacity plus $5 \%$ $\left(\mathrm{kg} \mathrm{kg}^{-1}\right)$ and equilibrated at $4{ }^{\circ} \mathrm{C}$ overnight before immersion in water (rewetted treatment). Coarse silt-sized $(5-53 \mu \mathrm{m})$, fine silt-sized $(2-5 \mu \mathrm{m})$, and clay-sized $(<2 \mu \mathrm{m})$ fraction were isolated by different centrifugation speed and time. Suspension with clay-sized fraction was flocculated with $0.2 \mathrm{~mol} \mathrm{~L}^{-1} \mathrm{CaCl}_{2}$, and then collected by centrifugation. Aggregates $(53-2000 \mu \mathrm{m})$ were retained on the sieve, and the centrifuged fractions were washed to aluminum boxes, first being evaporated in water bath, and then being put in an oven at $40{ }^{\circ} \mathrm{C}$ to a consistent weight (48-72 h) and finally being grounded by hand to pass through a $0.15 \mathrm{~mm}$ sieve for $\mathrm{C}, \mathrm{N}$, and $\delta^{13} \mathrm{C}$ analysis.

\subsection{Soil analysis}

The concentration of $\mathrm{OC}$ and total $\mathrm{N}$ in bulk soil and soil fractions were determined by $\mathrm{CN}$ Analysis using a Euro EA3000 (Eurovector, Milan, Italy). The $\delta^{13} \mathrm{C}$ value of OC in bulk soil and soil fractions were analyzed by an Isoprime MAT Delta Plus XL (Bremen, Germany). Since aggregates $(>53 \mu \mathrm{m})$ differed in content from other aggregate-sized class, SOC content was corrected on the sand-free basis ( $\mathrm{Six}$ et al. 1998). The recoveries of soil mass (97-101\%), SOC (88-106\%), and total nitrogen (94-110\%) after particle-sized fractionation averaged $99 \%, 102 \%$, and $93 \%$, respectively.

Soil OC and total $\mathrm{N}$ stocks $\left(\mathrm{t} \mathrm{ha}^{-1}\right)$ in bulk soil and soil fractions were calculated as:

$\mathrm{OC}(\text { total } \mathrm{N})_{\text {stock }}=\left(C \times A_{i} \times \mathrm{BD} \times d\right)$

In the above equation, $C$ was the concentration of $\mathrm{OC}$ (total $\mathrm{N}$ ) in bulk soil and soil fractions $\left(\mathrm{g} \mathrm{kg}^{-1}\right), A_{i}$ was the mass proportion of the $i$ fractions to the bulk soil (\%). $B D$ was the bulk density $\left(\mathrm{g} \mathrm{m}^{-3}\right)$, and $d$ was the soil depth $(0.20 \mathrm{~m})$.
Table 1 Annual amount of nitrogen $(\mathrm{N})$, phosphorus $(\mathrm{P})$, potassium $(\mathrm{K})$ fertilizer and manure applied for fertilization treatments in double maize system from year 1986 to 2010

\begin{tabular}{|c|c|c|c|c|}
\hline \multirow[t]{2}{*}{ Treatments } & \multicolumn{3}{|c|}{ Mineral fertilizer ${ }^{1}$} & \multirow{2}{*}{$\begin{array}{l}\text { Organic fertilizer } \\
2 \\
\text { Fresh pig manure }\left(\mathrm{kg} \mathrm{ha}^{-1}\right)\end{array}$} \\
\hline & $\mathrm{N}\left(\mathrm{kg} \mathrm{ha}^{-1}\right)$ & $\mathrm{P}_{2} \mathrm{O}_{5}\left(\mathrm{~kg} \mathrm{ha}^{-1}\right)$ & $\mathrm{K}_{2} \mathrm{O}\left(\mathrm{kg} \mathrm{ha}^{-1}\right)$ & \\
\hline Control & 0 & 0 & 0 & 0 \\
\hline NPK & 120 & 30 & 60 & 0 \\
\hline $2 \mathrm{NPK}$ & 240 & 60 & 120 & 0 \\
\hline M & 0 & 0 & 0 & 30,000 \\
\hline NPKM & 120 & 30 & 60 & 30,000 \\
\hline
\end{tabular}

${ }^{1}$ Mineral nitrogen fertilizer was a urea, mineral phosphorus fertilizer was a calcium-magnesia phosphate, and mineral potassium fertilizer was a potassium chloride

${ }^{2}$ The water content of fresh pig manure was $72 \%$. The organic carbon, nitrogen, phosphorus, and potassium content of pig manure was $376 \mathrm{~g} \mathrm{~kg}^{-1}, 33.14 \mathrm{~g} \mathrm{~kg}^{-1}, 23.77 \mathrm{~g} \mathrm{~kg}^{-1}$, and $15.09 \mathrm{~g} \mathrm{~kg}^{-1}$, respectively

The application rate of mineral fertilizer and organic fertilizer was half and half for each maize season. Fresh pig manure, potassium chloride, and calcium-magnesia phosphate were applied as basal fertilizes. A total of $70 \%$ of nitrogen in urea was applied as top dressing 1 week after seeding. Then, the rest of nitrogen fertilizer was applied 2 weeks after seeding 


\subsection{Statistical analysis}

One-way ANOVA was conducted to determine the effect of various fertilization treatments on the concentration and distribution of $\mathrm{OC}$ and total $\mathrm{N}$ in bulk soil and soil fractions using SPSS 22.0. Significant differences among various fertilization treatments were assessed by the LSD test at $5 \%$ levels for all the parameters. The linear and non-linear regression was performed to check the relationships between $\mathrm{OC}$ concentration (and total $\mathrm{N}$ ) in soil fractions and OC concentration (and total $\mathrm{N}$ ) in bulk soil, and between the mass proportion of soil particle fractions and $\mathrm{OC}$ concentration in soil particle fractions under various fertilization.

\section{Results}

\subsection{Soil OC and total $\mathrm{N}$ in bulk soil}

Long-term fertilization significantly changed SOC and total N concentration in double maize cropping system (Fig. 1). In bulk soil, SOC concentration was the highest in NPKM treatment $\left(9.89 \mathrm{~g} \mathrm{~kg}^{-1}\right.$ ), followed by $\mathrm{M}$ treatment (Fig. 1a). Compared with the starting year, SOC concentration significantly increased by $11 \%$ and $7 \%$ in NPKM and M treatments, respectively, while decreased by $18 \%$ in control treatment. Total $\mathrm{N}$ concentration was the highest $\left(1.14 \mathrm{~g} \mathrm{~kg}^{-1}\right)$ in NPKM treatment (Fig. 1b), followed by M treatment $\left(1.09 \mathrm{~g} \mathrm{~kg}^{-1}\right)$. As compared with the starting year, total $\mathrm{N}$ concentration significantly increased by $11 \%$ and $16 \%$ in NPKM and M treatments, respectively, while decreased by $18 \%$ in control treatment. Moreover, long-term fertilizer application did not significantly change soil $\mathrm{C} / \mathrm{N}$ ratios, except in NPK treatment (Fig. 1c).

\subsection{Soil particle-sized fraction and their association with $\mathrm{OC}$ and total $\mathrm{N}$}

Fractionation analysis showed that the mass proportion of coarse silt-sized fraction was the highest (with the average of $42 \%$ ), but the mass proportion of aggregates was the lowest (with the average of 6\%) (Table 2). Compared with control, fertilizer application increased the mass proportion of aggregates and clay-sized fraction, particularly in manure application (M and NPKM), the mass proportion increased by an average of 2.3 points and 15.8 points, respectively.

Results showed that OC concentration was the highest in aggregates (with the average of $21.07 \mathrm{~g} \mathrm{~kg}^{-1}$ fraction), but the lowest in coarse silt-sized fraction (with the average of $3.43 \mathrm{~g} \mathrm{~kg}^{-1}$ fraction) among all treatments (Fig. 1a). Compared with control, manure application (M and NPKM) increased OC concentration in aggregates, fine silt-sized fraction, and clay-sized fraction by an average of $76 \%, 42 \%$, and
$31 \%$, respectively. However, manure application ( $\mathrm{M}$ and NPKM) significantly decreased OC concentration by an average of $17 \%$ in coarse silt-sized fraction. As for total $\mathrm{N}$ concentration, it was the highest in clay-sized fraction ( $1.77 \mathrm{~g} \mathrm{~kg}^{-1}$ fraction), and the lowest in coarse silt-sized fraction $\left(0.27 \mathrm{~g} \mathrm{~kg}^{-1}\right.$ fraction), and it increased by an average of $52 \%$ and $26 \%$ in aggregates and clay-sized fraction under $\mathrm{M}$ and NPKM treatments, respectively, as compared with that under control treatment. Accordingly, soil $\mathrm{C} / \mathrm{N}$ ratio was the highest in aggregates (19.87), and the lowest in clay-sized fraction (6.16), showing a decreasing trend with the decrease of soil particle size (Fig. 1c). Compared with control, mineral fertilizer application (NPK and 2NPK) significantly increased $\mathrm{C} / \mathrm{N}$ ratio $(p<0.05)$ by 4.75 units in coarse silt-sized fraction, whereas manure application (M and NPKM) increased $\mathrm{C} / \mathrm{N}$ ratio by 5.13 units and 2.78 units $(p<0.05)$ in coarse silt-sized and fine silt-sized fractions, respectively.

The distribution proportions of $\mathrm{OC}$ and total $\mathrm{N}$ were the highest in clay-sized fraction ( $47 \%$ and $69 \%$, respectively), while the lowest in aggregates (14\% and 6\%, respectively) for all treatments (Table 2). Compared with control, manure application (M and NPKM) increased the distribution proportions of OC by an average of 7.2 points and 23.8 points, and total $\mathrm{N}$ by an average of 2.4 points and 17.3 points in aggregates and clay-sized fraction, respectively. Meanwhile, as for coarse silt-sized and fine silt-sized fraction, manure application decreased the distribution proportions of $\mathrm{OC}$ by an average of 17.1 points and 3.7 points, and total $\mathrm{N}$ by an average of 9.6 points and 10.0 points as compared with control treatment, respectively.

\subsection{Relationship between soil particle fractions and $\mathrm{OC}$ and total $\mathrm{N}$ accumulation}

The OC stock of aggregates was significantly positive correlated with that in bulk soil $(p<0.05$, Fig. 2a). There was a significant exponential relationship between SOC stock in clay-sized fraction and in bulk soil (Fig. 2d), but a significantly negative relationship between SOC stock in coarse siltsized fraction and in bulk soil (Fig. 2b). A significant exponential relationship between total $\mathrm{N}$ stocks in clay-sized fraction and in bulk soil was observed (Fig. 3d), whereas there was a significantly linear correlation appeared in aggregates $(p<0.05)$ (Fig. 3a).

The mass proportion of aggregates to bulk soil showed a significantly $(p<0.05)$ exponential growth with the increase in the concentration of fine silt-sized and clay-sized fractionassociated OC (Fig. 4a, b). However, a significant $(p<0.05)$ logarithmic decay trend was observed between the mass proportion of coarse silt-sized fraction and the concentration of fine silt-sized fraction-associated OC (Fig. 4c) and clay-sized fraction-associated OC (Fig. 4d). Furthermore, the mass ratio of aggregates to coarse silt-sized fraction and fine silt-sized 


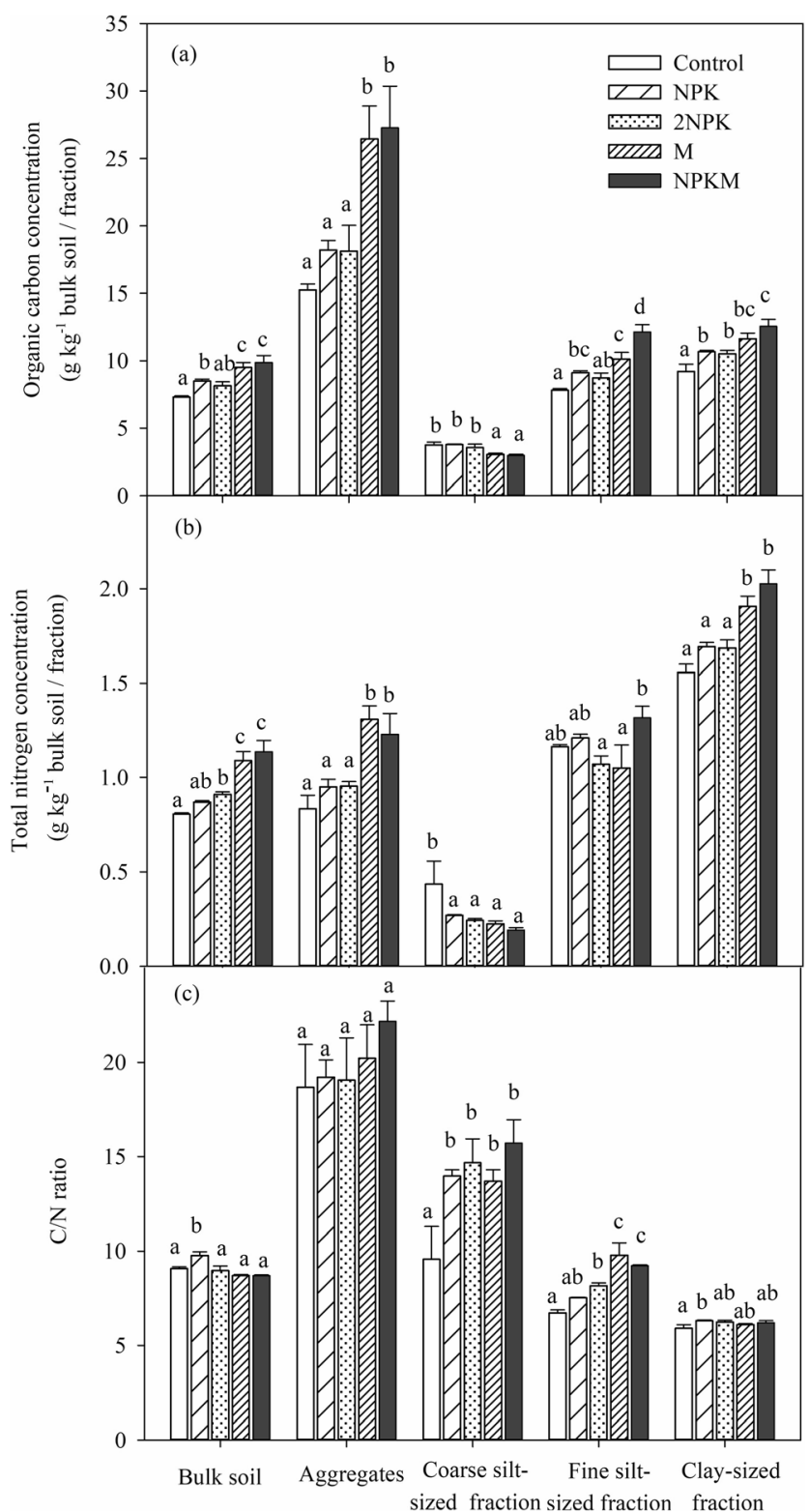

Fig. 1 Organic carbon (a), total nitrogen (b), and $\mathrm{C} / \mathrm{N}$ ratio (c) in bulk soil and soil fractions after 24-year fertilization (1986-2010) in double maize system. Aggregates $(53-2000 \mu \mathrm{m})$, coarse silt-sized fraction $(5-53 \mu \mathrm{m})$, fine silt-sized fraction $(2-5 \mu \mathrm{m})$, and clay-sized fraction $(<2 \mu \mathrm{m})$. Bars indicate SE $(n=3)$. Different letters above the bars indicate a significant difference in organic carbon (a), total nitrogen (b), and $\mathrm{C} / \mathrm{N}$ ratio (c) of bulk soil and soil fractions among different treatments at the $5 \%$ level

fraction also suggested a significantly positive and linear correlation with the concentration of fine silt-sized fraction-associated OC (Fig. 4e, g) and clay-sized fraction-associated OC (Fig. 4f, h).

\section{Discussion}

With the 24-year fertilization experiment, our study confirmed that manure application facilitated $\mathrm{OC}$ and total $\mathrm{N}$ accumulation in bulk soil. Fertilization, especially organic fertilizer application, mainly enhanced crop yields, consequently increasing the return amounts of stubble and root exudates in the previous study of this area (Zhang et al. 2015b), introducing a large amount of exogenous $\mathrm{C}$ and $\mathrm{N}$ into soil. Furthermore, the enhanced $\mathrm{C}$ and $\mathrm{N}$ accumulation might benefit physical and chemical protection of $\mathrm{OC}$ and $\mathrm{N}$ by soil aggregate formations (Campbell et al. 2001). Our findings showed the highest $\mathrm{OC}$ concentration in aggregates and highest total $\mathrm{N}$ in clay-sized fraction, which was in accordance with those reported by He et al. (2009) in northern China and Gelaw et al. (2015) in Northern Ethiopia. The possible reason was that the refractory and incompletely decomposed plant residues and stubble (with high $\mathrm{C} / \mathrm{N}$ ratios) were mainly accumulated in aggregates. Organic matter in clay-sized fraction is highly decayed by microbes with $\mathrm{N}$ enrichment and lower $\mathrm{C} / \mathrm{N}$ ratio. $\mathrm{OC}$ and $\mathrm{N}$ in clay-sized fraction was likely adsorbed and stabilized as organo-mineral complexes (Marx et al. 2005). Furthermore, our results indicated that annual additions of organic manure significantly decreased OC and total $\mathrm{N}$ concentration in coarse silt-sized fraction. The main reason might be that, other than the physical protection from aggregates and the chemical bonding from clay, coarse silt-sized fraction-associated OM was relatively easy to be decomposed by soil microbes (Vogel et al. 2015). This likely indicated that coarse silt-sized fraction-associated $\mathrm{C}$ and $\mathrm{N}$ were in an intermediate state of decay, and might have a relative fast turnover rate which could facilitate the stabilization of microbial products in clay-sized fraction.

According to the theory of aggregates turnover proposed by Six et al. (2002), plant residues which are not completely degraded are physically protected in coarse particle-sized fraction (Kirchmann et al. 2004). In this study, C/N ratio showed a decreasing trend with the decrease of particle sizes from 19.87 in aggregates to 6.16 in clay-sized fraction. Soil $\mathrm{C} / \mathrm{N}$ ratio usually decrease with the increase of residues decomposition. As the soil particle size decreased, the decomposition degree of soil particle fraction-associated OM increased gradually (Yan et al. 2012; Liang et al. 2014). Thus, clay-sized fraction shows a high degree of microbial decomposed organic matter (Gerzabek et al. 2006), and it is also particularly enriched by microbial debris and degradation products (Vogel et al. 2015). The $\mathrm{C} / \mathrm{N}$ ratio of 6.6 in clay-sized fraction in this study also suggests a possible source from fungi (C/N ratios of 15:1-5:1) and bacteria (C/N ratio of 5:1-3:1) (Amelung et al. 1998).

Our study found that about $47 \%$ of OC and $69 \%$ of total $\mathrm{N}$ were stored in the clay-sized fraction, indicating that claysized fraction played an important role in $\mathrm{C}$ and $\mathrm{N}$ sequestration in red soil. It might be due to the high concentrations of clay-sized fraction-associated $\mathrm{C}$ and $\mathrm{N}$, and the large mass proportion of clay-sized fraction $(35 \%)$ in this soil. These results were in agreement with Christensen (2001) and Long et al. (2015) that more $\mathrm{C}$ and $\mathrm{N}$ were stored in clay-sized 
Table 2 Mass proportion of soil fractions to bulk soil ( $\left.\mathrm{M}_{\%}, \%\right)$, the proportion of soil fraction-associated OC (C $\left.\%, \%\right)$ and total N (N\%, \%) to soil OC and total $\mathrm{N}$ under various fertilizations in double maize system, respectively

\begin{tabular}{|c|c|c|c|c|c|c|c|c|c|c|c|c|}
\hline \multirow[t]{2}{*}{ Treatments } & \multicolumn{3}{|c|}{ Aggregates $(53-2000 \mu \mathrm{m})$} & \multicolumn{3}{|c|}{ Coarse silt-sized fraction $(5-53 \mu \mathrm{m})$} & \multicolumn{3}{|c|}{ Fine silt-sized fraction $(2-5 \mu \mathrm{m})$} & \multicolumn{3}{|c|}{ Clay-sized fraction $(<2 \mu \mathrm{m})$} \\
\hline & $\mathrm{M}_{\%}{ }^{\#}$ & $\mathrm{C}_{\%}{ }^{\#}$ & $\mathrm{~N}_{\%}^{\#}$ & $\mathrm{M}_{\%}$ & $\mathrm{C}_{\%}$ & $\mathrm{~N}_{\%}$ & $\mathrm{M}_{\%}$ & $\mathrm{C}_{\%}$ & $\mathrm{~N}_{\%}$ & $\mathrm{M}_{\%}$ & $\mathrm{C}_{\%}$ & $\mathrm{~N}_{\%}$ \\
\hline Control & $4.29 \mathrm{a}$ & $10.01 \mathrm{a}$ & $4.58 \mathrm{a}$ & $44.81 \mathrm{~b}$ & $30.94 \mathrm{c}$ & & $13.38 \mathrm{ab}$ & & & $23.58 \mathrm{a}$ & $29.51 \mathrm{a}$ & $56.63 \mathrm{a}$ \\
\hline NPK & $6.11 \mathrm{~b}$ & $13.72 \mathrm{~b}$ & $6.25 \mathrm{~b}$ & $40.83 \mathrm{a}$ & $19.53 \mathrm{~b}$ & $6.25 \mathrm{~b}$ & $15.50 \mathrm{~b}$ & $17.90 \mathrm{~b}$ & $20.54 \mathrm{c}$ & $36.10 \mathrm{~b}$ & $48.85 \mathrm{~b}$ & $66.97 \mathrm{~b}$ \\
\hline $2 \mathrm{NPK}$ & $5.77 \mathrm{~b}$ & $13.38 \mathrm{~b}$ & $6.16 \mathrm{~b}$ & $41.28 \mathrm{a}$ & $19.12 \mathrm{~b}$ & $6.31 \mathrm{~b}$ & $13.57 \mathrm{ab}$ & $15.43 \mathrm{a}$ & $16.18 \mathrm{~b}$ & $37.92 \mathrm{~b}$ & $52.06 \mathrm{c}$ & $71.35 \mathrm{c}$ \\
\hline M & $6.02 \mathrm{~b}$ & $16.59 \mathrm{c}$ & $6.89 \mathrm{~b}$ & $40.44 \mathrm{a}$ & $14.48 \mathrm{a}$ & $4.56 \mathrm{a}$ & $12.80 \mathrm{a}$ & $14.68 \mathrm{a}$ & $12.84 \mathrm{a}$ & $39.97 \mathrm{~b}$ & $54.56 \mathrm{~cd}$ & $75.71 \mathrm{~d}$ \\
\hline NPKM & $7.17 \mathrm{~b}$ & $17.79 \mathrm{c}$ & $7.07 \mathrm{~b}$ & $40.67 \mathrm{a}$ & $13.13 \mathrm{a}$ & $5.38 \mathrm{ab}$ & $12.82 \mathrm{a}$ & $16.62 \mathrm{ab}$ & $15.45 \mathrm{ab}$ & $38.76 \mathrm{~b}$ & $52.10 \mathrm{c}$ & $72.09 \mathrm{~cd}$ \\
\hline
\end{tabular}

Data are means $(n=3)$. Different letters in the column indicate significant differences among different treatments at the 5\% levels

${ }^{\#} \mathrm{M}_{\%}$ represent the mass proportion of each soil fractions to bulk soil. $\mathrm{C}_{\%}\left(\mathrm{~N}_{\%}\right)$ represent the proportion of soil fraction-associated OC (total $\mathrm{N}$ ) to soil OC (total $\mathrm{N}$ ) in bulk soil

fraction than in other particle-sized fractions of soil. In addition, this result also highlighted the capacity of OM accumulation through organo-mineral interactions and adsorption, and its nonsusceptibility to microbial decomposition due to the strong physical-chemical protection (Diekow et al. 2005; Vogel et al. 2015). It is likely that clay-associated $\mathrm{C}$ and $\mathrm{N}$ is mainly semi-decomposed, and is relatively stable and hard to be decomposed due to the encapsulation of inorganic-organic compounds (Fernandez-Ugalde et al. 2016).

As the stubble and root exudates incorporated into soil, the $\delta^{13} \mathrm{C}$ value of SOC gradually approached the $\delta^{13} \mathrm{C}$ value of the above-ground growth plant (Bai et al. 2012). For the treatments without manure (control and NPK of which $\mathrm{C}$ was mainly derived from maize), the $\delta^{13} \mathrm{C}$ of soil particle- associated OC showed an increasing trend as decrease in particle size (see Electronic supplementary material, ESM, Table S1). The increment of the $\delta^{13} \mathrm{C}$ of OC in NPK treatment was relatively high than that in control treatment, especially in clay-sized fraction (Table S1, ESM). Its possible reason was that mineral fertilizer application enhanced maize yield and biomass, and correspondingly increased carbon input from maize in the previous study of this area (Zhang et al. $2015 b)$. In addition, the averaged value of $\delta^{13} \mathrm{C}$ in fine siltsized and clay-sized fraction showed a relative high abundance $\left(\delta^{13} \mathrm{C}\right.$ increased by 2.40 and 1.09 points, respectively) after 18 years for control and NPK treatments compared with the initial value (Table S1, ESM), whereas the increment was 0.78 points in the coarse silt-sized fractions. These results
Fig. 2 Relationship between organic carbon stock in bulk soil and organic carbon stock in aggregates (a), coarse silt-sized fraction (b), fine silt-sized fraction (c), and clay-sized fraction (d) after 24-year fertilization (19862010) in double maize system. Error bars represents the standard errors of organic carbon in bulk soil and soil fractions $(n=3) . R^{2}$ represents the determination coefficient of the linear equation

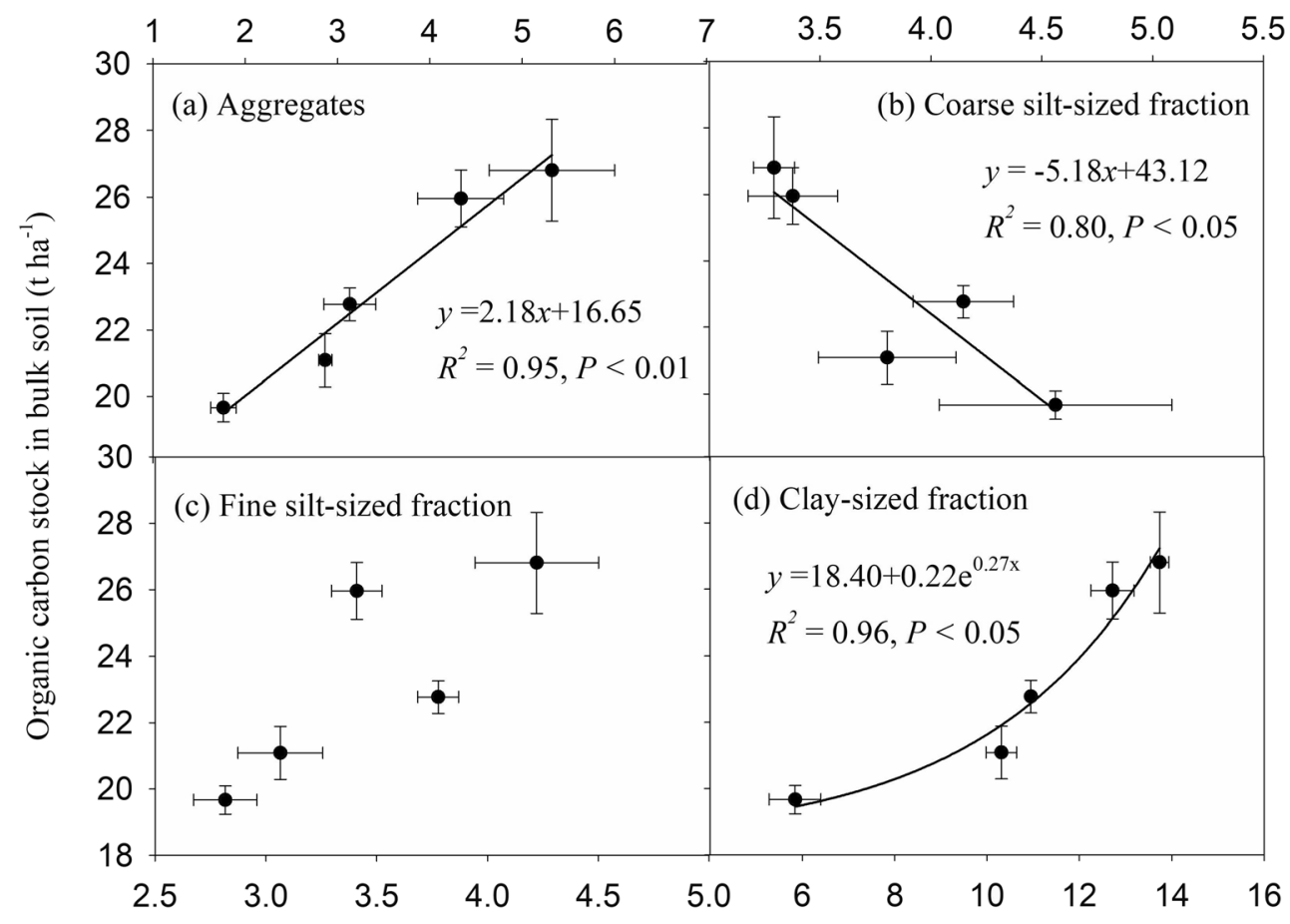

Organic carbon stock in soil fractions $\left(\mathrm{t} \mathrm{ha}^{-1}\right)$ 
Fig. 3 Relationship between total nitrogen in bulk soil and total nitrogen stock in aggregates (a), coarse silt-sized fraction (b), fine silt-sized fraction (c), and claysized fraction (d) after 24-year fertilization (1986-2010) in double maize system

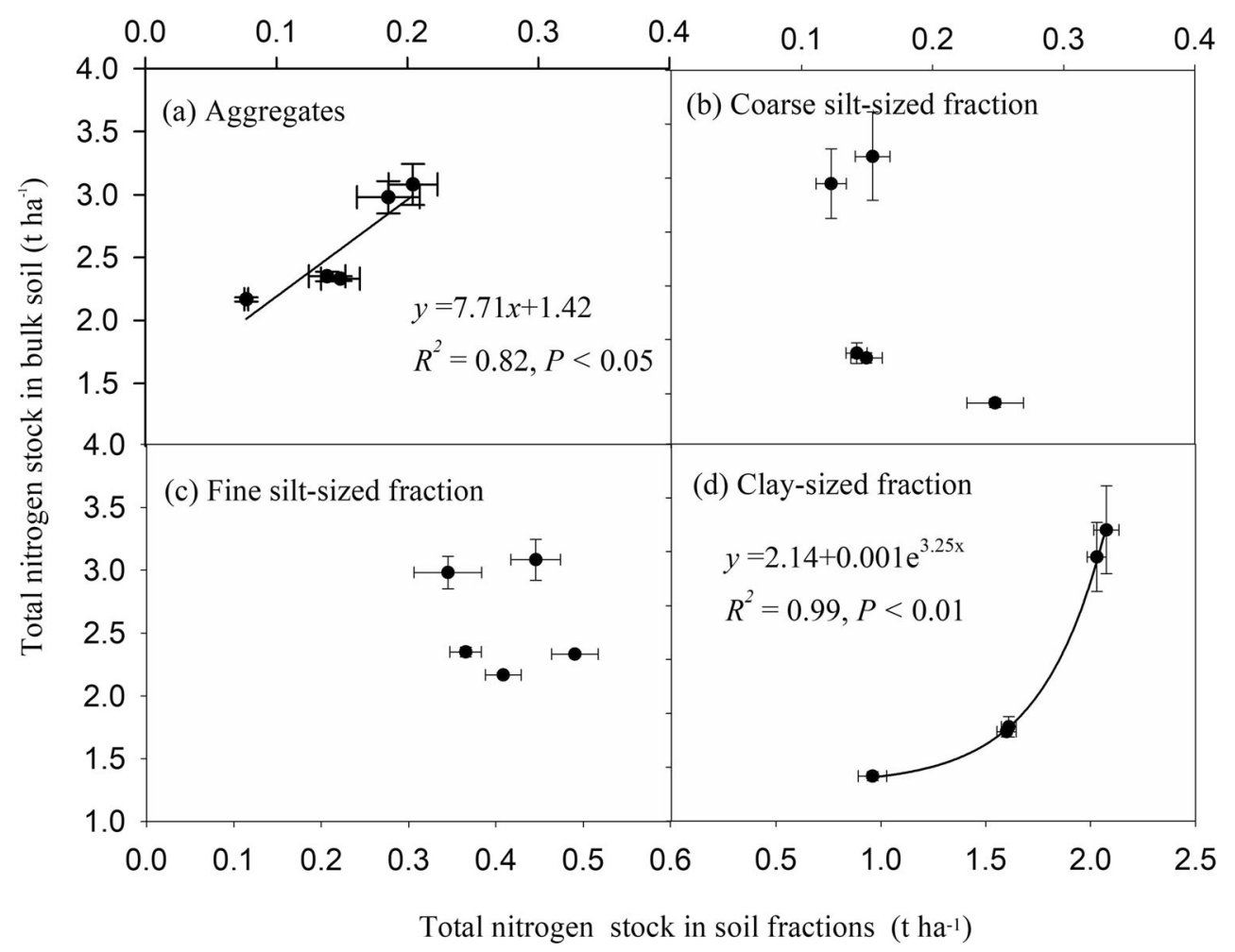

occupied (Gulde et al. 2008; Du et al. 2014). Our maximum estimation of clay-sized fraction-associated OC was lower than that of $32.50 \mathrm{~g} \mathrm{C} \mathrm{kg}^{-1}$ in a dark red latosol soil reported by Roscoe et al. (2001). It might be due to the high clay content $(>80 \%)$ for a dark red latosol soil (Roscoe et al. 2001), which was more than twice of the clay content (35\%) for red soil in our study. In addition, the intensive disturbing of double maize cropping in our study, might also contributed to the low capacity of the maximum estimation in the clay-sized fraction-associated OC, which was different from the cultivated pasture under natural conditions from Roscoe et al. (2001). The linear response of aggregate-associated $\mathrm{OC}$ and total $\mathrm{N}$ to soil $\mathrm{OC}$ and total $\mathrm{N}$ might also indicate that soil $\mathrm{OC}$ and total $\mathrm{N}$ stock would be further increased through aggregateassociated $\mathrm{OC}$ and total $\mathrm{N}$ after clay-sized fraction-associated OC and total $\mathrm{N}$ became saturated gradually (Carter 2002).

The significantly positive correlations revealed that the absolute content of aggregates (the mass proportion of aggregates) and relative content of aggregates (the mass ratio of the aggregates to coarse silt-sized fraction and fine silt-sized fraction) increased with the enrichment of $\mathrm{OC}$ in the fine soil minerals. However, the significantly negative correlations indicated that the amount of coarse silt-sized fraction gradually decreased with the increased of $\mathrm{OC}$ accumulation in fine soil particles. According to the theory of aggregate formation proposed by Tisdall and Oades (1982), soil aggregates form as OC in particle fractions associate with fine soil particles or microbial mucus, and then fine soil particles agglomerate 
Fig. 4 Relationship between the mass proportion of aggregates and the concentration of silt-sized fraction-associated OC (a), claysized fraction-associated $\mathrm{OC}$ (b); between the mass proportion of coarse silt-sized fraction and the concentration of silt-sized fraction-associated OC (c), claysized fraction-associated OC (d); between the mass ratio of aggregates to coarse silt-sized fraction and the concentration of silt-sized fraction-associated OC (e), clay-sized fraction-associated OC (f); between the mass ratio of aggregates to fine silt-sized fraction and the concentration of silt-sized fraction-associated OC (g), clay-sized fraction-associated OC (h) after 24-year fertilization (1986-2010) in double maize system. $R^{2}$ represents the determination coefficient of the linear equation

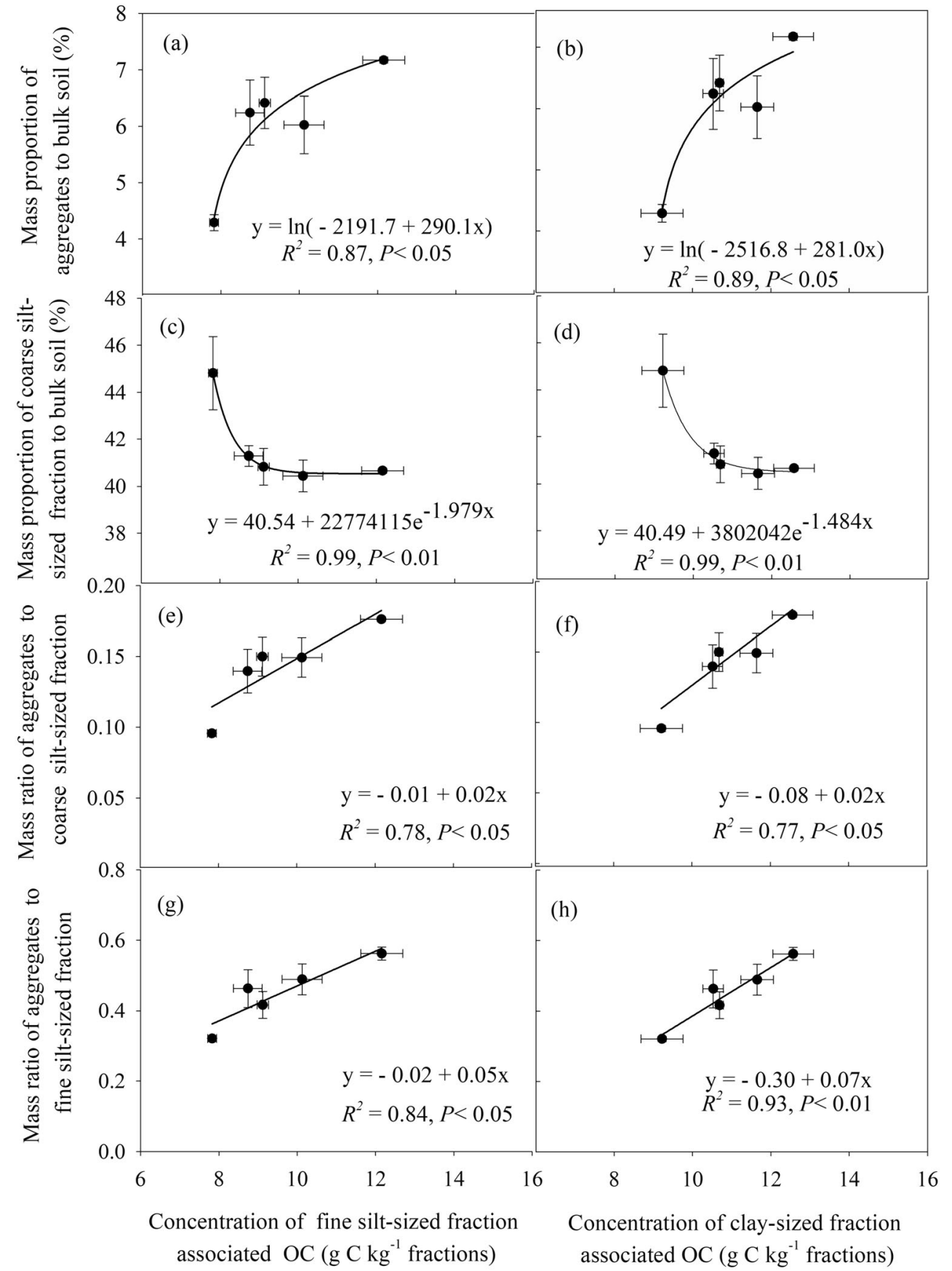

and form aggregates through organic binding agents. As organic matter can act as binding agents for soil aggregates formation (Six et al. 2002), we speculated that soil aggregation was facilitated by the binding of the enriched OC in fine soil particles (the silt-sized and clay-sized fractions) with the fine particles into aggregates, resulting in a decrease in the relative proportion of coarse silt-sized fraction. Those results also confirmed the theory that the soil aggregates hierarchically and continuously formed from small to large through organic binding agents (Tisdall and Oades.1982; Six et al. 2000; Six et al. 2002).

\section{Conclusions}

Manure application substantially enhanced $\mathrm{C}$ and $\mathrm{N}$ sequestration in bulk soil and fine soil particles, as well as aggregates in upland red soil. Fine soil particles, especially clay-sized fraction, were of great importance for $\mathrm{C}$ sequestration and $\mathrm{N}$ accumulation with a limited capacity. Soil OC and total $\mathrm{N}$ levels might further increase through its association with aggregates after clay-sized-associated $\mathrm{C}$ and $\mathrm{N}$ gradually reaches the upper limitation. Moreover, $\mathrm{C}$ accumulation in soil clay-sized particle benefited the formation of aggregates. In 
conclusion, organic amendments with fertilization can effectively enhance soil $\mathrm{C}$ and $\mathrm{N}$ sequestration through $\mathrm{C}$ and $\mathrm{N}$ accumulated in fine soil particles, as well as aggregates under intensive cropping in South China.

Acknowledgments We are very grateful to the reviewer for the insightful suggestions and comments which greatly improved the quality of the paper.

Funding information This work was financially supported by the National Natural Science Foundation of China (41371247, 41620104006) and Fundamental Research Funds for Central Non-profit Scientific Institution (No. 1610132019044). The China Scholarship Council (No. 201803250076) was also acknowledged.

\section{References}

Amelung W, Zech W, Zhang X, Follett RF, Tiessen H, Knox E, Flach KW (1998) Carbon, nitrogen, and sulfur pools in particle-size fractions as influenced by climate. Soil Sci Soc Am J 62:172-181

Antil RS, Gerzabek MH, Haberhauer G, Eder G (2005) Long-term effects of cropped vs. fallow and fertilizer amendments on soil organic matter - I. Organic carbon. J Plant Nutr Soil Sc 168:108-116

Aoyama M, Angers DA, N'Dayegamiye A (1999) Particulate and mineral-associated organic matter in water-stable aggregates as affected by mineral fertilizer and manure applications. Can J Soil Sci 79:295-302

Bai E, Boutton TW, Liu F, Wu XB, Archer SR (2012) Spatial patterns of soil $\delta 13 \mathrm{C}$ reveal grassland-to-woodland successional processes. Org Geochem 42(12):1512-1518

Balesdent J, Chenu C, Balabane M (2000) Relationship of soil organic matter dynamics to physical protection and tillage. Soil Till Res 53: $215-230$

Bell LW, Moore AD, Kirkegaard JA (2014) Evolution in crop-livestock integration systems that improve farm productivity and environmental performance in Australia. Eur J Agron 57:10-20

Bird M, Kracht O, Derrien D, Zhou YP (2003) The effect of soil texture and roots on the stable carbon isotope composition of soil organic carbon. Soil Res 41(1):77-94

Campbell CA, Selles F, Lafond GP, Biederbeck VO, Zentner RP (2001) Tillage - fertilizer changes: effect on some soil quality attributes under long-term crop rotations in a thin black chernozem. Can J Soil Sci 81:157-165

Carter MR (2002) Soil quality for sustainable land management: organic matter and aggregation interactions that maintain soil functions. Agron J 94:38-47

Castellano MJ, Mueller KE, Olk DC, Sawyer JE, Johan Six J (2015) Integrating plant litter quality, soil organic matter stabilization, and the carbon saturation concept. Glob Chang Biol 21:3200-3209

Chan KY, Heenan DP, Oates A (2002) Soil carbon fractions and relationship to soil quality under different tillage and stubble management. Soil Till Res 63:133-139

Christensen BT (2001) Physical fractionation of soil and structural and functional complexity in organic matter turnover. Eur J Soil Sci 52: 345-353

Denef K, Zotarelli L, Boddey RM, Six J (2007) Microaggregateassociated carbon as a diagnostic fraction for management-induced changes in soil organic carbon in two oxisols. Soil Biol Biochem 39: $1165-1172$

Diekow J, Mielniczuk J, Knicker H, Bayer C, Dick DP, Kogel-Knabner I (2005) Carbon and nitrogen stocks in physical fractions of a subtropical Acrisol as influenced by long-term no-till cropping systems and $\mathrm{N}$ fertilisation. Plant Soil 268:319-328

Dong XL, Hao QY, Li GT, Lin QM, Zhao XR (2017) Contrast effect of longterm fertilization on SOC and SIC stocks and distribution in different soil particle-size fractions. J Soils Sediments 17:1054-1063

Du ZL, Wu WL, Zhang QZ, Guo YB, Meng FQ (2014) Long-term manure amendments enhance soil aggregation and carbon saturation of stable pools in North China plain. J Integr Agr 13:2276-2285

Fan JL, McConkey BG, Liang BC, Angers DA, Janzen HH, Kröbel R, Cerkowniak DD, Smith WN (2019) Increasing crop yields and root input make Canadian farmland a large carbon sink. Geoderma 336: $49-58$

FAO (1988) Soil map of the world. Revised Legend. FAO World Soil Resources Report, Rome, Italy

Fernandez-Ugalde O, Barre P, Virto I, Hubert F, Billiou D, Chenu C (2016) Does phyllosilicate mineralogy explain organic matter stabilization in different particle-size fractions in a 19 -year C-3/C-4 chronosequence in a temperate Cambisol? Geoderma 264:171-178

Gelaw AM, Singh BR, Lal R (2015) Organic carbon and nitrogen associated with soil aggregates and particle sizes under different land uses in Tigray, Northern Ethiopia. Land Degrad Dev 26:690-700

Gerzabek MH, Antil RS, Kogel-Knabner I, Knicker H, Kirchmann H, Haberhauer G (2006) How are soil use and management reflected by soil organic matter characteristics: a spectroscopic approach. Eur J Soil Sci 57:485-494

Ghimire R, Lamichhane S, Acharya BS, Bista P, Sainju UM (2017) Tillage, crop residue, and nutrient management effects on soil organic carbon in rice-based cropping systems: a review. J Integr Agr 16:1-15

Gulde S, Chung H, Amelung W, Chang C, Six J (2008) Soil carbon saturation controls labile and stable carbon pool dynamics. Soil Sci Soc Am J 72:605-612

Guo JH, Liu XJ, Zhang Y, Shen JL, Han WX, Zhang WF, Christie P, Goulding KWT, Vitousek PM, Zhang FS (2010) Significant acidification in major Chinese croplands. Science 327:1008-1010

Hassink J (1997) The capacity of soils to preserve organic C and N by their association with clay and silt particles. Plant Soil 191:77-87

He NP, Wu L, Wang YS, Han XG (2009) Changes in carbon and nitrogen in soil particle-size fractions along a grassland restoration chronosequence in northern China. Geoderma 150:302-308

Huang S, Peng X, Huang Q, Zhang W (2010) Soil aggregation and organic carbon fractions affected by long-term fertilization in a red soil of subtropical China. Geoderma 154:364-369

Kirchmann H, Haberhauer G, Kandeler E, Sessitsch A, Gerzabek MH (2004) Effects of level and quality of organic matter input on carbon storage and biological activity in soil: synthesis of a long-term experiment. Global Biogeochem Cy 18. https://doi.org/10.1029/2003GB002204

Koiter AJ, Owens PN, Petticrew EL, Lobb DA (2017) The role of soil surface properties on the particle size and carbon selectivity of interrill erosion in agricultural landscapes. Catena 153:194-206

Leinweber P, Reuter G (1992) The influence of different fertilization practices on concentrations of organic carbon and total nitrogen in particle-size fractions during 34 years of a soil formation experiment in loamy marl. Biol Fert Soils 13:119-124

Liang Q, Chen HQ, Gong YS, Yang HF, Fan MS, Kuzyakov Y (2014) Effects of 15 years of manure and mineral fertilizers on enzyme activities in particle-size fractions in a North China plain soil. Eur J Soil Biol 60:112-119

Ling N, Sun YM, Ma JH, Guo JJ, Zhu P, Peng C, Yu GH, Ran W, Guo SW, Shen QR (2014) Response of the bacterial diversity and soil enzyme activity in particle-size fractions of Mollisol after different fertilization in a long-term experiment. Biol Fert Soils 50:901-911

Long P, Sui P, Gao WS, Wang BB, Huang JX, Yan P, Zou JX, Yan LL, Chen YQ (2015) Aggregate stability and associated C and N in a silty loam soil as affected by organic material inputs. J Integr Agr 14:774-787

Marx MC, Kandeler E, Wood M, Wermbter N, Jarvis SC (2005) Exploring the enzymatic landscape: distribution and kinetics of 
hydrolytic enzymes in soil particle-size fractions. Soil Biol Biochem 37:35-48

Paustian K, Lehmann J, Ogle S, Reay D, Robertson GP, Smith P (2016) Climate-smart soils. Nature 532:49-57

Poeplau C, Reiter L, Berti A, Kaetterer T (2017) Qualitative and quantitative response of soil organic carbon to 40 years of crop residue incorporation under contrasting nitrogen fertilisation regimes. Soil Res 55:1-9

Roscoe R, Buurman P, Velthorst EJ, Vasconcellos CA (2001) Soil organic matter dynamics in density and particle size fractions as revealed by the $(13) \mathrm{C} /(12) \mathrm{C}$ isotopic ratio in a Cerrado's oxisol. Geoderma 104: 185-202

Schulten HR, Leinweber P (1991) Influence of long-term fertilization with farmyard manure on soil organic matter: characteristics of particle-size fractions. Biol Fert Soils 12:81-88

Six J, Elliott ET, Paustian K, Doran JW (1998) Aggregation and soil organic matter accumulation in cultivated and native grassland soils. Soil Sci Soc Am J 62:1367-1377

Six J, Paustian K, Elliott ET, Combrink C (2000) Soil structure and organic matter: I. Distribution of aggregate-size classes and aggregate-associated carbon. Soil Sci Soc Am J 64:681-689

Six J, Conant RT, Paul EA, Paustian K (2002) Stabilization mechanisms of soil organic matter: implications for $\mathrm{C}$-saturation of soils. Plant Soil 241:155-176

Tisdall JM, Oades JM (1982) Organic matter and water-stable aggregates in soils. Eur J Soil Sci 33:141-163

Vogel C, Heister K, Buegger F, Tanuwidjaja I, Haug S, Schloter M, Koegel-Knabner I (2015) Clay mineral composition modifies decomposition and sequestration of organic carbon and nitrogen in fine soil fractions. Biol Fert Soils 51:427-442
Wen YL, Liu WJ, Deng WB, He XH, Yu GH (2019) Impact of agricultural fertilization practices on organo-mineral associations in four long-term field experiments: implications for soil $\mathrm{C}$ sequestration. Sci Total Environ 651:591-600

Wu TY, Schoenau JJ, Li FM, Qian PY, Malhi SS, Shi YC (2005) Influence of fertilization and organic amendments on organiccarbon fractions in Heilu soil on the loess plateau of China. J Plant Nutr Soil Sc 168:100-107

Xu MG, Zhang WJ, Huang SM, Yang XY, Lu CA, He YT, Han XZ (2015) Soil fertility evolution in China, 2th edn. China Agricultural Science and Technology Press, Beijing

Yan Y, He H, Zhang X, Chen Y, Xie H, Bai Z, Zhu P, Ren J, Wang L (2012) Long-term fertilization effects on carbon and nitrogen in particle-size fractions of a Chinese Mollisol. Can J Soil Sci 92: 509-519

Zhang WJ, Wang XJ, Xu MG, Huang SM, Liu H, Peng C (2010) Soil organic carbon dynamics under long-term fertilizations in arable land of northern China. Biogeosciences 7:409-425

Zhang Q, Zhou W, Liang G, Sun J, Wang X, He P (2015a) Distribution of soil nutrients, extracellular enzyme activities and microbial communities across particle-size fractions in a long-term fertilizer experiment. Appl Soil Ecol 94:59-71

Zhang WJ, Liu KL, Wang JZ, Shao XF, Xu MG, Li JW, Wang XJ, Murphy DV (2015b) Relative contribution of maize and external manure amendment to soil carbon sequestration in a long-term intensive maize cropping system. Sci Rep 5:10791

Publisher's note Springer Nature remains neutral with regard to jurisdictional claims in published maps and institutional affiliations. 